\title{
Citrullinemic Lymphocytes in Long Term Culture
}

\author{
E. B. Spegtor ${ }^{[17]}$ and A. D. Bloom \\ Department of Human Genetics, University of Michigan Medical School, Ann Arbor, Michigan, USA
}

\begin{abstract}
Extract
Peripheral blood lymphocytes from a 33-year-old male with citrullinemia were established in long term, continuous culture. This lymphocyte line was designated UM-21 (University of Michigan, lymphoid line no. 21), and the behavior of the cells of this line was studied under selective conditions in vitro. When arginine was removed from the medium and replaced with citrulline, the UM-21 lymphocytes were unable to enter logarithmic growth phase. This contrasted with lymphocyte lines from normal donors which were able to utilize the citrulline readily and to grow logarithmically. We interpreted this as presumptive evidence that, unlike normal lymphocytes, the citrullinemic lymphocytes were deficient in argininosuccinic acid synthetase (AS). Despite the initial inability of the citrullinemic lymphocytes to grow logarithmically in a medium with $200 \mathrm{mg} /$ liter citrulline substituted for the normally used arginine ( $\mathrm{Cit}^{+}, \mathrm{Arg}^{-}$medium), after 4 weeks of continuous incubation some cells did begin to divide and a variant of the UM-21 line was subsequently established.

Cells from the parental UM-21 line, the variant line, and two normal lymphocyte lines were incubated with ureido- ${ }^{14} \mathrm{C}$-citrulline to determine their relative uptake and incorporation of citrulline. On autoradiography, the UM-21 cells showed no label. Cells from the variant line showed a diverse labeling pattern: $11.7 \%$ of cells were heavily labeled, $32.4 \%$ were lightly labeled, and $55.9 \%$ showed no label. The cells from the normal donors were uniformly heavily labeled. Further, the incorporation of label into trichloroacetic acid-precipitable cellular material was examined. UM-2 1 incorporated $360 \mathrm{cpm}$, the variant line $1,95 \mathrm{l} \mathrm{cpm}$, and the two normal lines 2,544 and $2,427 \mathrm{cpm}$, respectively. The counts per minute are here expressed per $10^{5}$ cells, or 3.3-3.5 $\times 10^{-3} \mathrm{mg}$ protein.
\end{abstract}

\section{Speculation}

Although a more sensitive assay for AS will have to be developed for lymphocyte lines, it is apparent from the data presented here that the citrullinemic defect is expressed in cultured lymphocytes under proper selective conditions. The basic defect in this disease is likely to be either a regulatory or structural gene mutation, and the variant line may represent a reverse mutation. It may prove possible to study each of the four known genetically determined disorders of urea metabolism by use of the cultured lymphocyte.

\section{Introduction}

Citrullinemia is one of four amino acidurias associated with the Krebs-Henseleit urea cycle (Fig. 1). The disease is thought to be due to a deficiency of the normal liver enzyme argininosuccinate synthetase (AS), which catalyzes the conversion of citrulline plus aspartate to argininosuccinic acid [10]. Although the degree of mental retardation is variable in this disease, the levels 

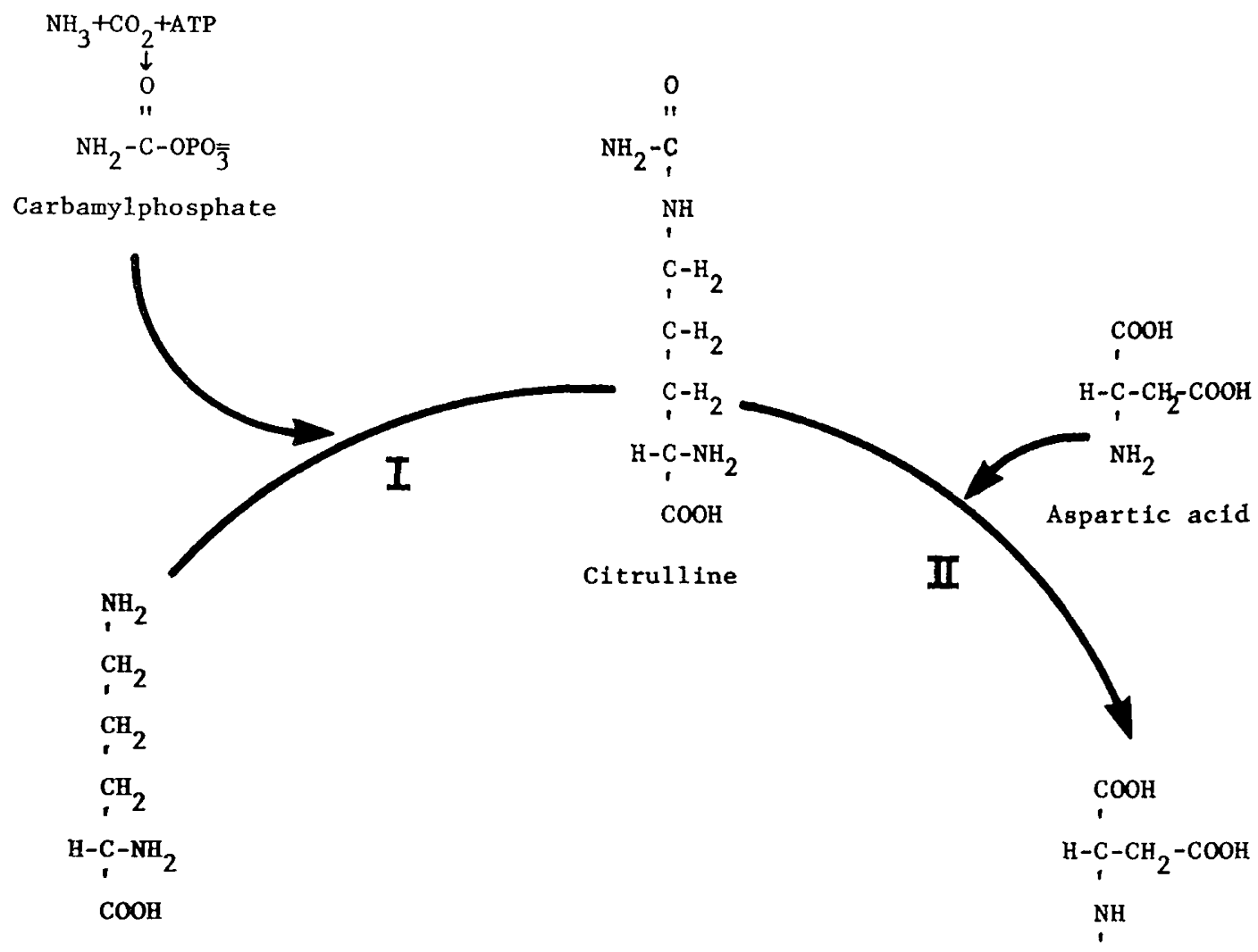

Ornithine
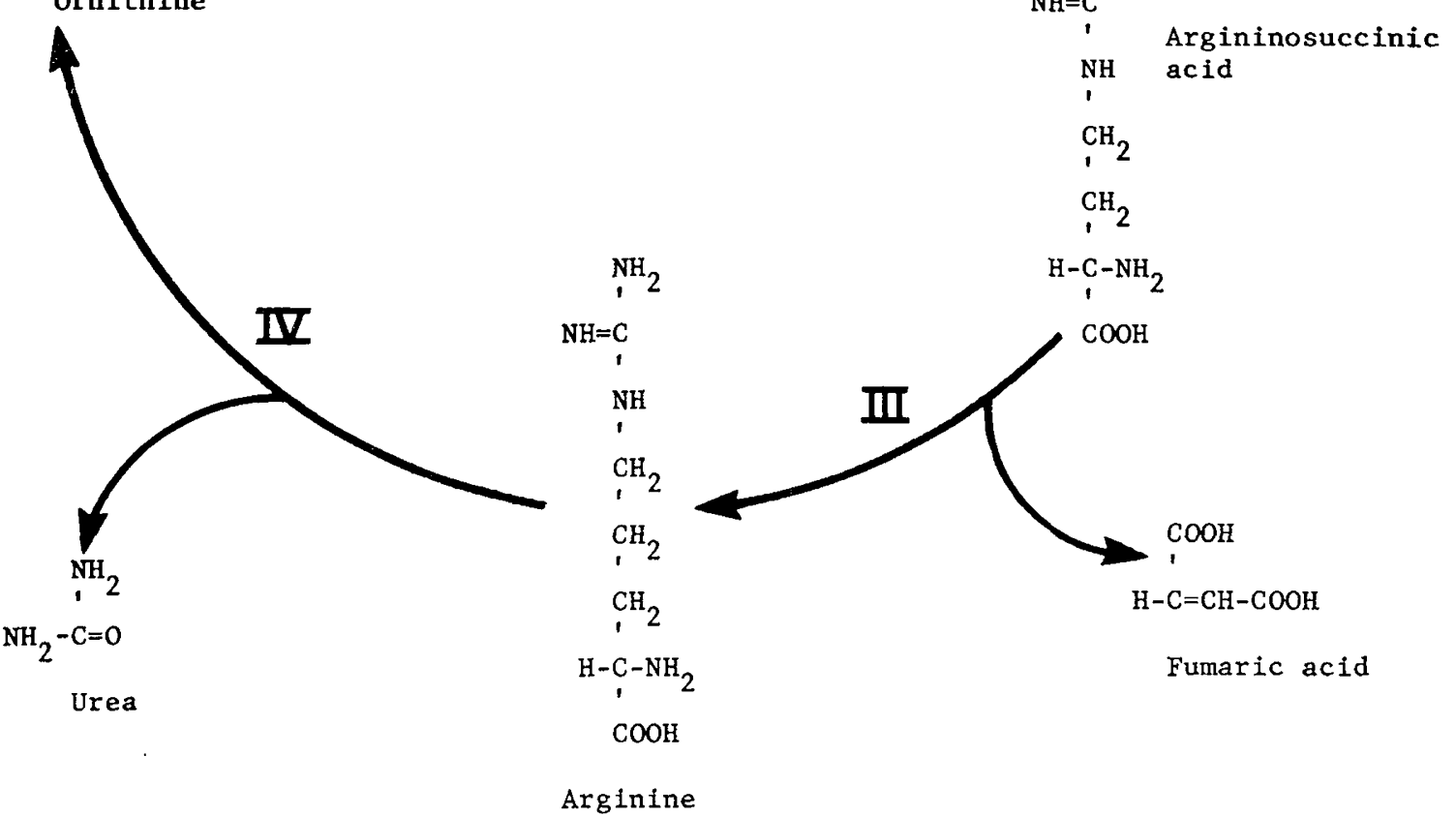

Fig. 1. The Krebs-Henseleit urea cycle. The block at $I$ results from ornithine transcarbamylase deficiency; at $I I$, the argininosuccinic acid synthetase defect results in citrullinemia; at $I I I$, argininosuccinase deficiency results in argininosuccinic aciduria; and at $I V$, lysine intolerance results, apparently from an inhibition of arginase activity. 
of citrulline in serum, urine, and cerebrospinal fluid are usually elevated [4-6]. Patients with citrullinemia have sporadic episodes of convulsions which are presumed to be associated with ammonia intoxication, despite the fact that the levels of arginine and ornithine as well as the production of urea are often normal.

The particular patient from whom we established this first citrullinemic lymphocyte line was a 33-yearold mentally retarded male, described in detail by Scott-Emuakpor et al. [8]. This patient differed from the patients with citrullinemia described earlier $[4,6]$ in that he had a reasonably efficient ammonia removal mechanism. Our interest in establishing his lymphocytes in long term culture was, first, to determine whether or not the citrullinemic defect was expressed in cultured lymphoblasts, and, second, to determine whether his cells were genetically homogeneous in their inability to utilize citrulline.

\section{Methods and Materials}

\section{Lymphocyte Lines}

The continuously propagated lymphocyte lines used in this study were established by the lysate method, described originally by Choi and Bloom [2]. The cell lysate used contains the Epstein-Barr virus which is thought to play a role in the establishment and continuous propagation of the cell lines. To date, no effect of the viral genome on the metabolic function of the host cells has been found. Cell line UM-10 was established in April 1970 from a 10-year-old male with the LeschNyhan syndrome. Cell line UM-21 was established in July 1970 from the patient with citrullinemia described above. Cell line UM-4.3 was derived from a normal 22-year-old male and has been in continuous culture since January 1971. Each line has a modal chromosome number of 46 , with an XY chromosome con. stitution.

\section{Growth Medium}

Lymphocytes were maintained in Roswell Park Memorial Institute medium (RPMI) 1640 with 20\% fetal calf serum, penicillin, and streptomycin. This medium normally contains $200 \mathrm{mg} /$ liter arginine. For the growth experiments, $0.3 \times 10^{6}$ cells $/ \mathrm{ml}$ were grown in three types of media: RPMI with $200 \mathrm{mg} /$ liter arginine (Cit- $\left.{ }^{-} \operatorname{Arg}^{+}\right)$; RPMI with $200 \mathrm{mg} /$ liter citrulline substituted for arginine (Cit ${ }^{+}, \mathrm{Arg}^{-}$); and RPMI without citrulline or arginine ( $\left.\mathrm{Cit}^{-}{ }^{-}, \mathrm{Arg}^{-}\right)$. Total cells were counted every $48 \mathrm{hr}$ in a hemacytometer, and viability was determined by trypan blue dye exclusion [11].

\section{Autoradiography}

Cells from UM-10 and UM-21 (parent and variant) were used in this experiment. We incubated $5 \times 10^{5}$ logarithmically growing cells for $48 \mathrm{hr}$ in medium containing $1 \mu \mathrm{Ci} / \mathrm{ml}$ ureido- ${ }^{14} \mathrm{C}$-citrulline (sp act 3.73 $\mathrm{mCi} / \mathrm{mm}$ [12]). The cells were washed three times with Hanks' balanced salt solution and centrifuged at 1,000 rpm. They were then resuspended in fetal calf serum, placed on slides, and dipped in Kodak NTB-3 emulsion. After 5 days of exposure, the slides were developed in D-19 for $3 \mathrm{~min}$.

\section{${ }^{14} \mathrm{C}$-Citrulline Incorporation into Cellular Protein}

Cells $\left(5 \times 10^{5}\right)$ from each line were inoculated into each of three test tubes in $4 \mathrm{mI}$ medium containing no citrulline, arginine, or fetal calf serum and incubated for $12 \mathrm{hr}$ at $37^{\circ}$. This medium was then replaced with an equal volume of medium containing $175 \mathrm{mg} /$ liter cold citrulline and $1 \mu \mathrm{Ci} / \mathrm{ml}$ ureido $-{ }^{14} \mathrm{C}$ citrulline (sp act $3.73 \mathrm{mCi} / \mathrm{mm}$ [12]). The cells were incubated in this medium for an additional $12 \mathrm{hr}$. The cells were then pipetted into a filter apparatus containing glass fiber filter paper [13]. They were then washed successively with approximately $40 \mathrm{ml}$ each $0.85 \%$ saline, $5 \%$ cold trichloroacetic acid, and absolute methanol. The filter papers were allowed to air dry and then placed in scintillation vials with $0.5 \mathrm{ml}$ Soluene [14] and incubated at $37^{\circ}$ overnight. The counts per minute in the trichloroacetic acid precipitate were determined in a Packard Tri-Carb scintillation counter model 3320 [14].

Milligrams of protein were determined by a modification of the Lowry method [3].

\section{Determination of Doubling Times}

Cultures for estimation of the population doubling times were initiated with $0.3 \times 10^{6}$ cells $/ \mathrm{ml}$. The UM21 cells were placed in $\mathrm{Cit}^{-}, \mathrm{Arg}^{+}$medium. The UM21 variant (capable of growing in citrulline) was inoculated into $\mathrm{Cit}^{+}, \mathrm{Arg}^{-}$medium. The UM-10 cell line was studied in both $\mathrm{Cit}^{-}, \mathrm{Arg}^{+}$and $\mathrm{Cit}^{+}$, Arg- medium. The cell count was determined at 24-hr intervals with a hemacytometer, and the doubling times were calculated by the method of Aoki and Moore [I].

\section{Assay for Argininosuccinate Synthetase}

Lines UM-10, UM-21, and UM-43 were assayed by Dr. P. Snodgrass using a spectrophotometric assay first 
described by R. T. Schinke [7]. Packed cells $(0.4 \mathrm{ml})$ were used in the determinations. UM-10 contained $8.77 \mathrm{mg}$ protein $/ \mathrm{ml}$, UM-21 contained $15.0 \mathrm{mg}$ protein $/ \mathrm{ml}$, and UM-43 contained $8.75 \mathrm{mg}$ of protein $/ \mathrm{ml}$.

\section{Results}

\section{Growth Curves}

The results are presented in Fig. 2. The UM-10, UM-43, and UM-21 cells grown in RPMI $1640 \mathrm{Cit}^{-}$, $\mathrm{Arg}^{+}$showed normal logarithmic growth and reached a maximum live cell density of $1 \times 10^{6}$ cells $/ \mathrm{ml}$ before being subcultured. The UM-10 and UM-43 cells grown

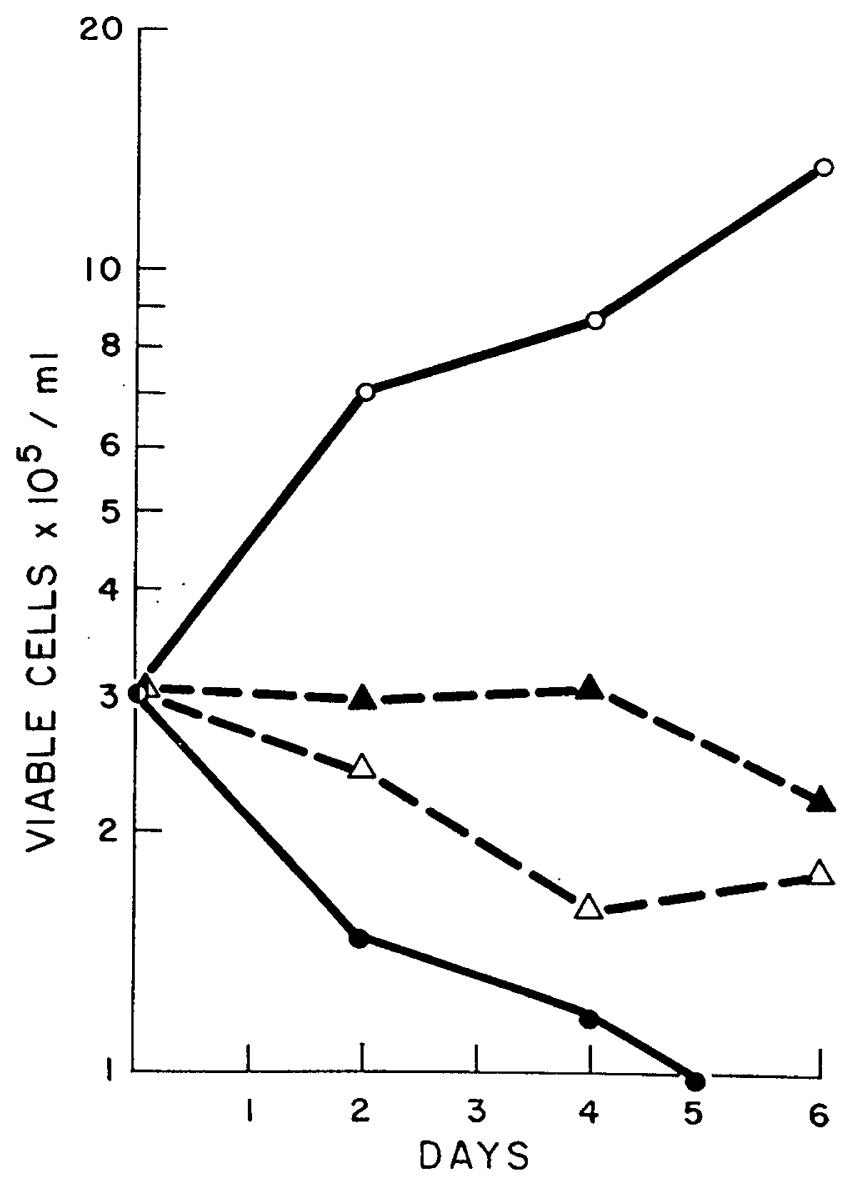

Fig. 2. Cronth of "normal" (UM-10) and citrullinemic (UM-21) lymphocytes in medium which contains no arginine and $20 \mathrm{mg} /$ $100 \mathrm{ml}$ citrulline $\left(\mathrm{Cit}^{+}, \mathrm{Arg}^{-}\right)$or in medium which contains no citrulline or arginine (Cit- $\left.\mathrm{Arg}^{-}\right)$. Inoculations of $0.3 \times 10^{\text {s }}$ cells/ ml were made into each of the two types of media. The total number of viable cells was determined every $48 \mathrm{hr}$ with trypan blue dye exclusion. The UM-10 cells in $\mathrm{Cit}^{+}, \mathrm{Arg}^{-}$medium are represented by $\mathrm{O}-\mathrm{O}$, the UM-10 cells in Cit-, Arg- medium by $-\bullet$, the UM-2I cells in $\mathrm{Cit}^{+}$, Arg- medium by $\triangle-\triangle$, and the L:M-21 cells in Cit ${ }^{-}$, Arg- medium by in $\mathrm{Arg}^{-}$, Cit- medium died within 6 (lays, whereas UM-2I cells could be maintained for a month in this medium before senescence. The UM-10 and UM-43 cells grown in $\mathrm{Cit}^{+}$, $\mathrm{Arg}^{-}$medium also showed nor-. mal logarithmic growth, whereas UM-2l cells failed to grow in this medium. However, most of the UM-21 cells did remain viable, and the concentration of cells in the original population $\left(0.2 \times 10^{\text {is }}\right.$ cells $\left./ \mathrm{ml}\right)$ was maintained for $3-4$ weeks. These cells were incubated continuously thereafter in $\mathrm{Cit}^{+}, \mathrm{Arg}^{-}$medium, and after a month the cells began to increase in number. Those cells which were able to grow in the presence of citrulline constitute a population of cells different from the parental line and are referred to as the UM21 variant cells. They were maintained in $\mathrm{Cit}^{+}, \mathrm{Arg}^{-}$ RPMI 1640 medium. Nine clones of the parental UM21 line are now being studied.

\section{Doubling Times}

The UM-10 cells in Cit ${ }^{+}$, Arg- RPMI 1640 doubled in $24.6 \mathrm{hr}$, whereas the UM-21 variant cells failed to enter logarithmic growth phase. However, UM-10 and UM-21 in $\mathrm{Cit}^{-}$, $\mathrm{Arg}^{+}$medium had doubling times of 23.8 and $27.3 \mathrm{hr}$, respectively. Thus, there was no significant difference between the doubling times of cells from UM-10 that had been growing in medium containing citrulline or in medlum containing arginine. The UM-2 1 cells grown in medium containing arginine had a doubling time similar to that of the UM-10 cells. However, the UM-21 variant cells that had been incubated in medium with citrulline cloubled only once in 6 day's.

\section{Autoradiography}

Cells from UM-10 were labeled heavily and uniformly with ${ }^{14} \mathrm{C}$ while cells from UM-21 showed no label at all (Fig. 3). The UM-21 variant cells showed a diverse labeling pattern: $11.7 \%$ of cells were labeled heavily (more than 20 grains/cell), similar to the UM10 cells; $32.4 \%$ of cells were lightly labeled (11-20 grains per cell), i.e., they had incorporated some label but not as much as the UM-10 cells; and $55.9 \%$ of cells had incorporated essentially no label (less than 10 grains), as was the case for the UMI-2I cells.

\section{${ }^{14}$ C-Citrulline Incorporation}

When cells were incubated for $12 \mathrm{hr}$ with labeled citrulline, the precipitate from the UM-43 cells had $2,544 \mathrm{cpm}$; that from UMr-10 cells, $2,427 \mathrm{cpm}$; that from UM-21, $360 \mathrm{cpm}$; and that from UM-21 variant cells, 1,951 cpm. The counts per minute are expressed 


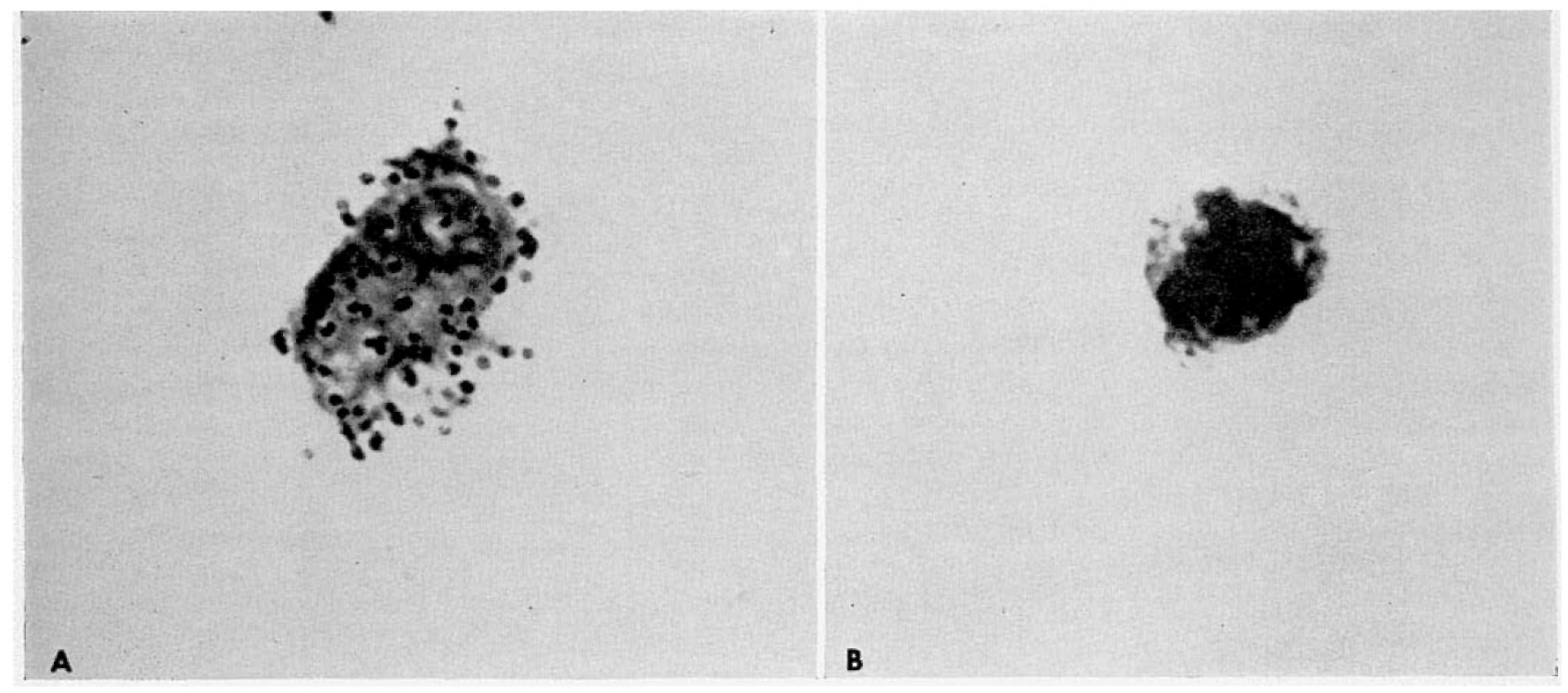

Fig. 3. Autoradiography of "normal" (UM-10) and citrullinemic (UM-21) lymphocytes with ureido-14C-citrulline. We incubated $0.5 \times$ $10^{5}$ cells for $48 \mathrm{hr}$ with $1 \mu \mathrm{Ci} / \mathrm{ml}$ label. $A$ : Heavy labeling found in the UM-10 cells; $B$ : complete absence of label in a UM-21 cell.

per $10^{5}$ cells, which is equivalent to $3.3-3.5 \times 10^{-3} \mathrm{mg}$ protein.

The mean counts per minute of the four samples were compared using Duncan's new multiple range test [9]. There is no significant difference $(P<0.01)$ between the mean counts of UM-10, UM-43, and UM21 variant, but the means of these three samples do differ significantly $(P<0.01)$ from the mean counts of UM-21.

\section{Direct Enzyme Assay}

No AS was detectable in any of the three lines tested, UM-43, UM-21, and UM-10, which indicates that the level of this enzyme in lymphocyte lines from citrullinemic and noncitrullinemic donors is very low. In the future, a more sensitive radioactive assay for AS will have to be used.

\section{Discussion}

Despite the fact that AS was not detectable spectrophotometrically in the lymphocyte lines used in this study, we have considerable indirect evidence here for the expression of this enzyme in lymphocytes established from "normal" donors, and for its lack of expression in UM-21, the citrullinemic cell line. Cells from UM21 were unable to enter logarithmic growth in medium in which citrulline had been substituted for arginine. These cells also showed a reduced uptake of la- beled ${ }^{14} \mathrm{C}$-citrulline on autoradiography and a markedly reduced incorporation of labeled citrulline into trichloroacetic acid-precipitable cellular protein.

Our isolation of a metabolic variant of UM-21 may have direct relevance to the clinical situation in this patient. The cells of the variant line showed a heterogeneous labeling pattern but incorporated ${ }^{14} \mathrm{C}$-citrulline into cellular protein almost as efficiently as the normal lymphocytes. These findings suggest that some cells from within this citrullinemic patient may have normal or nearly normal citrulline metabolism. Metabolic cooperation between normal and deficient cells might account for the seeming ease with which the patient disposes of ammonia and excretes normal amounts of urea.

Alternatively, and more likely, the variant line could be derived from a back mutation that occurred in vitro during the 2 years that the cells have been in culture. These "normal" or revertant cells might then have been selected for when the UM-21 cells were grown in $\mathrm{Cit}^{+}, \mathrm{Arg}^{-}$medium. The variant line may be comprised of cells with normal activity or of cells with partial activity that survive in selective medium through metabolic cooperation. The fact that the variant line had to be subcultured at a high population density for growth to occur suggests, however, that these cells do not have normal enzyme activity.

The basic defect in citrullinemia is not yet known, although the studies of Tedesco and Mellman [10] on 
citullinemic fibroblasts suggest a structural gene mutation. They found that the AS in citrullinemic fibroblasts has an increased $K_{m}$ for its substrate, and concluded that a structurally altered enzyme would be compatible with the reduced ability of the cells to utilize citrulline.

\section{Summary}

Peripheral blood lymphocytes were obtained from a patient with citrullinemia and established in continuous culture. These cells were unable to utilize citrulline in the growth medium and failed to incorporate ureido- ${ }^{-14} \mathrm{C}$-citrulline into cellular protein, which suggests either that they were defective in argininosuccinate synthetase or that they have a primary defect in citrulline transport. Under selective conditions, a variant line arose, which represented either a back mutation or a second in vivo cell population.

\section{Addendum}

Assay for argininosuccinate synthetase was recently performed on cell lines UM-43 and UM-21 by Dr. Nancy Kennaway, Department of Pediatrics, University of Oregon Medical School, using a modification of the Schimke method [7]. Dr. Kennaway found the specific activity for the synthetase in UM-43 to be 0.059 $\mu \mathrm{mol} / \mathrm{mg}$ protein/hr, while the UM-21 parent line had no detectable activity, which confirms the absence of catalytically active synthetase in the cells of this citrullinemic patient.

\section{References and Notes}

1. Aokr, Y., AND Moore, G. E.: Comparative study of mitotic stages of cells derived from human peripheral blood. Exp. Cell Res., 59: 259 (1970).
2. Chol, K. W., AND BI.oOM, A. D.: Cloning human lymphocytes in vitro. Nature, 227: 171 (1970).

3. Lowry, O. H., Rosebrough, N. J., Fark, A. L., AND RANdall, R. J.: Protein measurement with the Folin phenol reagent. J. Biol. Chem., 193: 265 (1951).

4. McMurray, W. C., Rathbun, J. C., Mohyuddin, F., and Kofgler, S. J.: Citrullinemia. Pediatrics, 32: 347 (1963).

5. Mohyuddin, F., Rathbun, J. G., and McMurray, W. C.: Studies on amino acid metabolism in citrullinuria. Amer. J. Dis. Child., 113: 152 (1967).

6. Morrow, G., Barness, L. A., and Erron, M. L.: Citrullinemia with defective urea production. Pediatrics, 40:565 (1967).

7. Schimke, R. T.: Enzymes of arginine metabolism in mammalian cell culture. I. Repression of argininosuccinic synthetase and argininosuccinase. J. Biol. Chem., 239: 136 (1964).

8. Scott-Emuakpor, A., Higgins, J. V., and Kohrman, A. F.: Citrullinemia: A new case, with implications concerning adaptation to defective urea synthesis. Pediat. Res., 6: 626 (1972).

9. Steel, R. G. D., And Torrie, J. H.: Principles and Procedures of Statistics, p. 107. (McGraw-Hill, New York, 1960).

10. Tedesco, T. A., and Mellman, W. J.: Argininosuccinate synthetase activity and citrulline metabolism in cells cultured from a citrullinemic subject. Proc. Nat. Acad. Sci. U. S. A., 57: 829 (1967).

11. Tennant, J. R.: Evaluation of the trypan blue technique for determination of cell viability. Transplantation, 2: 685 (1964).

12. New England Nuclear Corporation, Boston, Mass.

13. GF/A, Whatman-Reeve Angel, Clifton, N. J.

14. Packard Instrument Company, Downer's Grove, Ill.

15. We thank Dr. J. V. Higgins for obtaining peripheral blood from the patient described in Reference 8.

16. This research was supported by National Institutes of Health Program Project Grant no. 5-T0I-GM-71-15, National Institute of General Medical Sciences, and National Institutes of Health Training Grant in Genetics 0-10-141.

17. Requests for reprints should be addressed to: Elarne B. SPECTOR, Department of Human Genetics, School of Medicine, University of Michigan, Ann Arbor, Mich. 48104 (USA).

18. Accepted for publication March 13, 1973. 